\title{
LEVERAGE, UKURAN DEWAN KOMISARIS, UKURAN DEWAN PENGAWAS SYARIAH DAN PENGARUHNYA TERHADAP PENGUNGKAPAN ISLAMIC SOCIAL REPORTING (ISR)
}

\author{
Isnan Murdiansyah \\ Universitas Islam Negeri Malang \\ $\triangle$ isnanmurdiansyah86@gmail.com
}

\begin{abstract}
The purpose of this research is to find out the influence of leverage, size of the board of commissioners and sharia supervisory board toward the disclosure of Islamic Social Reporting (ISR) at Sharia Commercial Bank in Indonesia during 2017-2019 and test it. Purposing sampling is the technique that been used in this research with the samples 12 Sharia Commercial Bank during 3 years observation respectively with the result obtained 36 samples. The analysis technique used in this research was multiple regressions. The analysis result shows that leverage has no significant influenced toward the disclosure of Islamic Social Reporting (ISR), size of the board of commissioners has a positive significant influenced toward the disclosure of Islamic Social Reporting (ISR) and syaria supervisory board has no significant influenced toward the disclosure of Islamic Social Reporting (ISR).
\end{abstract}

Keywords : Size of the board of commissioners, Leverage, Sharia Supervisory Board, Disclosure of Islamic Social Reporting (ISR)

\section{LATAR BELAKANG}

Kajian mengenai konsep pertanggungjawaban sosial telah banyak dilakukan oleh para peneliti terdahulu karena pertanggungjawaban sosial atau Corporate Social Reporting (CSR) dianggap sebagai inti dalam etika bisnis. Adanya gagasan mengenai Corporate Social Reporting (CSR) menjadikan perusahaan dituntut tidak hanya mengacu pada konsep single bottom line saja yaitu corporate value melainkan juga mengacu pada konsep tripple buttom line (3P) yaitu laba (Profit), manusia (People) dan lingkungan (Planet), akan tetapi pada tahun 2010 bulan November awal terdapat peluncuran IS0 26000 oleh lembaga International Organisazation for standardization (ISO) mengenai pedoman dalam tanggung jawab sosial, dalam hal ini konsep triple bottom line (3P) ditambah dengan aspek prosedur (Prosedure), harapannya perusahaan melakukan tanggung jawabnya dengan cara menyisihkan laba (Profit) yang diperolehnya untuk upaya pengembangan manusia (people) serta lingkungan (planet) sesuai prosedur (Procedure) yang tepat (Fauziah \& J., 2013).

Regulasi mengenai pelaporan pertanggungjawaban sosial (CSR) di Indonesia tertuang dalam UU No. 40 tahun 2007 yang telah disahkan pada tanggal 20 juli 2007. Dalam pasal 74 undang-undang tersebut menyatakan bahwa suatu perusahaan yang menjalankan kegiatan usahanya tidak lagi melakukan pengungkapan pertanggungjawaban sosial (CSR) secara sukarela (voluntary) melainkan 
pengungkapannya bersifat wajib dilakukan (mandatory). (sawitri, Juanda, \& Jati, 2017). Dengan adanya hal tersebut pelaporan pertanggungjawaban sosial (CSR) di Indonesia mengalami perkembangan yang cukup baik, hal ini dapat dilihat dari banyaknya perusahaan yang menyajikan pertanggungjawaban sosialnya ke dalam laporan keuangan tahunan ataupun press relesa lainnya (Fitria \& Hartanti, 2010).

Pelaporan pertanggungjawaban sosial sekarang tidak lagi diartikan sebagai beban yang mana dengan menyisihkan sebagian keuntungan yang didapatkannya untuk disalurkan untuk kepentingan lain, tetapi sekarang menilai pertanggungjawaban sosial sebagai sebuah investasi yang mana dengan perusahaan menyajikan laporan pertanggungjawaban sosial secara baik dapat memperoleh imbal balik yakni menjadikan perusahaan mendapat citra positif, baik dari pihak internal maupun eksternal. Dengan citra positif tersebut tidak menutup kemungkinan jika perusahaan akan lebih maju karena mendapat anggapan baik dari sekitar sehingga dapat memperbaiki keuangan, menaikkan citra merk sekaligus dapat menambah daya tarik perusahaan tersebut (Zanariatin, Bayinah, \& Syahroni, 2016)

Beberapa fenomena dan hasil penelitian sebelumnya menunjukkan implementasi pertanggungjawaban sosial (CSR) tidak hanya berkembang pada lingkup konvensional, melainkan juga pada lingkup syariah. Saat ini semakin banyak perusahaan yang menerapkan kegiatannya berdasarkan prinsip syariah. Dalam islam kita dianjurkan untuk selalu meneladani sifat dan sikap yang dicontohkan oleh Nabi Muhammad SAW serta para sahabat karena beliau merupakan sebaik baik umat serta merupakan seorang utusan dari Allah SWT untuk menyempurnakan akhlak manusia, selain itu yang paling utama dalam melakukan segala sesuatu hendaknya kita merujuk kepada Al-Qur'an al Kariim karena Al-Qur'an bukan hanya sebagai kitab suci semata melainkan Al-Qur'an merupakan sebuah petunjuk bagi seluruh umat manusia yang didalamnya memuat segala solusi dari permasalahan yang ada di muka bumi seperti dalam hal hukum, ekonomi, politik, sosial dan lain sebagainya. Dalam islam manusia diartikan sebagai khalifah di bumi yang mana tugas manusia tidak cukup hanya untuk beribadah kepada Allah SWT semata (habluminallah) melainkan juga dibarengi dengan berlaku baik kepada makhluk hidup lainnya (habluminannas), pun dalam menjalankan kegiatannya baik dalam hal ekonomi, sosial dan lainnya islam mengajarkan untuk melakukannya bukan hanya berorientasi untuk kepentingan dunia saja tetapi yang terpenting adalah untuk memperoleh keridhoan-Nya.

Konsep Pertanggungjawaban sosial dalam islam erat kaitannya dengan suatu perusahaan yang menjalankan kegiatannya sesuai dengan prinsip syariah. Lembaga yang menjalankan prinsip syariah tersebut menjadikan Al-Qur'an dan As-Sunnah sebagai dasar dalam melaksanakan kegiatannya, salah satunya yakni pada perbankan syariah yang mana fungsi dari bank syariah sendiri yaitu sebagai perantara untuk kesejahteraan bersama dalam hal ekonomi.

Dengan semakin berkembangnya bank syariah di Indonesia, secara tidak langsung menunjukkan bahwa kebutuhan masyarakat dalam kaitannya dengan lembaga syariah semakin bertambah, hal ini tentunya menjadi tantangan tersendiri bagi perbankan syariah untuk terus berkembang lebih baik lagi, salah satunya dengan meningkatkan kepercayaan stakeholder dengan melaporkan pengungkapan pertanggungjawaban sosialnya.

Di Indonesia pengungkapan pada bank syariah termuat dalam PSAK No. 101 tahun 2006 tentang penyajian laporan keuangan syariah, namun PSAK ini hanya berlaku untuk laporan keuangan saja, tidak untuk informasi lain yang disajikan dalam laporan tahunan, sehingga terdapat perbedaan dikarenakan belum adanya standar 
khusus dalam penyajian laporannya, baik dari tema yang diungkapkan, tingkat pengungkapan, tipe pengungkapan dan lain lain. Sehingga hal ini menjadi pemicu pemikiran tentang Pelaporan pertanggungjawaban sosial berdasarkan nilai-nilai islam yang sering disebut dengan Islamic Social Reporting (ISR) (Abadi, Mubarok, \& Sholihah, 2020).

Konsep ISR pertama kali digagas oleh Ros Haniffa pada tahun 2002 yang kemudian dikembangkan oleh Othman et al di Malaysia. Konsep ini muncul dilatarbelakangi oleh pandangan Ros haniffa yang menyatakan bahwa adanya suatu keterbatasan dalam laporan pertanggungjawaban sosial konvensional, sehingga terbentuklah konsep Islamic Social Reporting (ISR) (Kurniawati \& Yaya, 2017). Munculnya konsep ISR ini diharapkan dapat melahirkan konsep dan praktik akuntansi yang sesuai dengan syariat islam. Instrumen tersebut dapat memberikan kontribusi kepada kemajuan bisnis yang lebih jujur dan adil karena ISR sendiri mempunyai dua tujuan utama yakni sebagai bentuk akuntabilitas kepada Allah SWT dan masyarakat serta dapat digunakan untuk meningkatkan transparansi kegiatan bisnis dengan memperhatikan kebutuhan spiritual investor muslim atau kepatuhan syariah dalam pengambilan keputusan (Abadi, Mubarok, \& Sholihah, 2020).

Indeks ISR berisi kompilasi item-item standar CSR yang ditetapkan oleh AAOIFI (Accounting and Auditing Organization for Islamic Financial Institutions) yang kemudian dikembangkan lebih lanjut oleh para peneliti (Hanifa, 2002; Maali et al, 2006; Ousama dan Fatima, 2006; Sulaiman, 2005; Othman et al, 2009) mengenai item-item CSR yang seharusnya diungkapkan oleh suatu entitas islam (Fitria \& Hartanti, 2010). Indeks ISR tersebut berisi 6 (enam) tema antara lain: investasi dan keuangan, produk dan jasa, karyawan, masyarakat, lingkungan, serta tata kelola perusahaan (Sutapa \& Laksito, 2018). Dalam praktiknya, perbankan syariah belum sepenuhnya menerapkan kegiatannya sesuai prinsip syariah seperti pada pelaporan pertanggungjawabannya, sampai saat ini pengukuran pertanggungjawaban bank syariah masih mengacu pada Global Reporting Initiative Index (Indeks GRI). hal tersebut dapat dilihat pada laporan sustainability, seperti yang terlihat pada laporan sustainability Bank Syariah Mandiri (BSM) (Awaliyah \& Vestari, 2018).

Berdasarkan (Haniffa, 2002) penggunaan indeks GRI dalam menilai lembaga keuangan syariah kurang tepat dilakukan karena menurut alat ukur pelaporan pertanggungjawaban antara lembaga syariah dan lembaga konvensional haruslah berbeda, hal tersebut disebabkan karena pada hakikatnya suatu informasi yang disajikan antara perspektif syariah dan perspektif konvensional terdapat perbedaan, yang mana informasi dalam lembaga syariah tidak seluruhnya termuat dalam lembaga konvensional. Namun pada penelitian yang dilakukan oleh (Syahputri \& Surenggono, 2019) bank umum syariah yang mengungkapkan pertanggungjawaban sosialnya berdasarkan indeks GRI menghasilkan skor yang lebih tinggi yaitu sebesar $54,40 \%$ sedangkan pengungkapan menggunakan indeks ISR menghasilkan skor yang lebih rendah yaitu sebesar $52,75 \%$ penelitian lain juga dilakukan oleh (Muthmainnah, Lubis, \& Zamzami, 2017) yang menunjukkan hasil yang sama bahwa pengungkapan pertanggungjawaban sosial pada perbankan syariah dengan menggunakan indeks GRI menghasilkan skor yang lebih tinggi daripada pengungkapan menggunakan indeks ISR. Hal tersebut menunjukkan kurangnya perhatian terhadap pelaporan pertanggungjawaban sosial berdasarkan prinsip syariah yaitu islamic social reporting (ISR). 
Disamping fenomena tersebut terdapat beberapa bank umum syariah yang sudah mengungkapkan pelaporan pertanggungjawaban sosial berbasis syariah islamic social reporting tetapi belum mencapai hasil yang maksimal, seperti penelitian yang dilakukan oleh (Putra, 2014) dengan meneliti 4 bank Umum syariah di Indonesia pada tahun 2012-2013, dalam penelitian ini diperoleh hasil bahwa dari semua sampel belum ada yang mampu mengungkapkan sebanyak 100\%, dari keseluruhan, 3 diantaranya dapat melebihi angka 50\%. Penelitian lain juga telah dilakukan oleh (Andraeny, 2016) yang melakukan penelitian pada 11 bank umum syariah di Indonesia. Penelitian tersebut memperoleh hasil bahwa pengungkapan pertanggungjawaban sosial dengan menggunakan indeks ISR masih berada pada rate $35 \%$ dari total keseluruhan pengungkapan. Kemudian penelitian dengan tahun terbaru dilakukan oleh (Qulub, Amin, \& Junaidi, 2019), berikut prosentase pengungkapan islamic social reporting bank umum syariah di Indonesia:

Tabel 1. Pengungkapan ISR Bank Umum Syariah

Tahun 2016-2018

\begin{tabular}{c|l|c|c|c|c|c|c}
\hline \multirow{2}{*}{ No } & \multirow{2}{*}{$\begin{array}{c}\text { Bank Umum } \\
\text { Syariah (BUS) }\end{array}$} & \multicolumn{2}{|c|}{$\mathbf{2 0 1 6}$} & \multicolumn{2}{c|}{$\mathbf{2 0 1 7}$} & \multicolumn{2}{c}{2018} \\
\cline { 2 - 8 } & Skor & Nilai & Skor & Nilai & Skor & Nilai \\
\hline 1 & BMI & 36 & $67,9 \%$ & 37 & $69,8 \%$ & 37 & $68,9 \%$ \\
\hline 2 & BMSI & 37 & $69,8 \%$ & 37 & $69,8 \%$ & 38 & $71,7 \%$ \\
\hline 3 & BSM & 42 & $79,2 \%$ & 41 & $79,2 \%$ & 40 & $75,5 \%$ \\
\hline 4 & BRIS & 34 & $64,2 \%$ & 36 & $64,2 \%$ & 38 & $71,7 \%$ \\
\hline 5 & BNIS & 39 & $73,6 \%$ & 39 & $73,6 \%$ & 40 & $75,5 \%$ \\
\hline 6 & BCAS & 32 & $60,4 \%$ & 37 & $60,4 \%$ & 38 & $71,7 \%$ \\
\hline 7 & BSB & 33 & $62,3 \%$ & 33 & $62,3 \%$ & 33 & $62,3 \%$ \\
\hline 8 & BACS & 37 & $69,8 \%$ & 37 & $69,8 \%$ & 37 & $69,8 \%$ \\
\hline 9 & BVIS & 28 & $52,8 \%$ & 28 & $52,8 \%$ & 28 & $52,8 \%$ \\
\hline 10 & BPDBS & 36 & $67,9 \%$ & 35 & $67,9 \%$ & 35 & $66,0 \%$ \\
\hline 11 & BJBS & 33 & $62,3 \%$ & 33 & $62,3 \%$ & 34 & $64,2 \%$ \\
\hline 12 & BTPNS & 32 & $60,4 \%$ & 32 & $60,4 \%$ & 32 & $60,4 \%$ \\
\hline \multirow{2}{*}{13} & Maybank & & & & & & \\
& Syariah & 33 & $62,3 \%$ & 33 & $62,3 \%$ & 33 & $62,3 \%$
\end{tabular}

Sumber : (Qulub, Amin, \& Junaidi, 2019)

Berdasarkan Tabel 1.2 diatas dapat disimpulkan bahwa bank umum syariah telah melakukan pengungkapan pertanggungjawaban sosial dengan indeks ISR, namun pengungkapan yang dilakukan dinilai masih kurang dan belum mencapai titik maksimal yaitu 100\%, hal tersebut dikarenakan belum adanya standar baku yang mengatur pengungkapan pertanggungjawaban sosial berbasis syariah.

Dalam mengungkapkan ISR terdapat beberapa faktor faktor yang dinilai mempunyai potensi pengaruh terhadap pengungkapan islamic Social Reporting (ISR). Faktor-Faktor tersebut terdiri dari rasio keuangan berupa profitabilitas yang dalam penelitian ini menggunakan Return On Asset (ROA) dan leverage menggunakan Debt to Equity (DER) kemudian juga terdapat ukuran dewan komisaris serta ukuran dewan pengawas syariah. Profitabilitas merupakan suatu rasio yang digunakan untuk melihat besar kecilnya tingkat keuntungan yang diperoleh. Semakin tinggi nilai profitabilitas maka menggambarkan semakin baik kemampuan untuk menghasilkan keuntungan (Fahmi, 2017). Dalam hal ini profitabilitas dinilai berpengaruh karena berdasarkan Luoet. al. dalam (Cahya, Nuruddin, \& Ikhsan, 2017) mengatakan bahwa 
perusahaan dengan kinerja keuangan yang baik cenderung mampu mengambil keputusan terhadap lingkungan sekitar, sementara itu perusahaan dengan kinerja keuangan yang buruk cenderung hanya berfokus pada pencapaian tujuan keuangan serta berupaya meningkatkan kinerja. Hal ini sesuai dengan penelitian yang dilakukan oleh oleh (Lestari, 2013) dan (Othman, Thani, \& Ghani, 2009) menyatakan bahwa variabel profitabilitas berpengaruh signifikan terhadap pengungkapan ISR, berbeda halnya dengan penelitian yang telah dilakukan oleh (Sunarsih \& Ferdiyansyah, 2017) dan (Rosiana, Arifin, \& Hamdani, 2015) yang menyatakan bahwa variabel profitabilitas tidak berpengaruh signifikan terhadap ISR.

Leverage juga dinilai berpengaruh dalam pengungkapan ISR. Leverage merupakan suatu rasio yang digunakan untuk melihat seberapa besar perusahaan dibiayai dengan utang. Berdasarkan (Rostiani \& Sukanta, 2018) menyatakan bahwa tingkat leverage yang tinggi cenderung membuat perusahaan lebih sedikit melakukan pengungkapan sosialnya karena lebih memilih untuk mengembalikan utang kepada para kreditur. Hal tersebut sesuai dengan penelitian oleh (Ramadhani, 2016) mengungkapkan bahwa variabel leverage berpengaruh terhadap pengungkapan ISR, Sedangkan hasil lain diteliti oleh (Rama \& Meliawati, 2014) yang menyatakan bahwa variabel leverage tidak berpengaruh terhadap pengungkapan Islamic Social Reporting (ISR).

Pengungkapan ISR juga dinilai dapat dipengaruhi ukuran dewan dewan komisaris, karena dewan komisaris dinilai sebagai mekanisme pengendalian internal tertinggi pada perusahaan, sehingga semakin banyak dewan komisaris dalam suatu perusahaan maka dapat dikatakan semakin baik pengendaliannya karena meminimalisir informasi yang ditutupi termasuk dalam pengungkapan islamic social reporting (ISR) (Istifaroh \& Subardjo, 2017). Pernyataan tersebut sesuai dengan hasil penelitian yang dilakukan oleh (Kurniawati \& Yaya, 2017) mengungkapkan bahwa ukuran dewan komisaris berpengaruh signifikan terhadap pengungkapan Islamic Social Reporting (ISR) sedangkan hasil berbeda diperoleh dalam penelitian (Hasanah, Widiyanti, \& Sudarno, 2017) dengan hasil bahwa ukuran dewan komisaris tidak berpengaruh terhadap pengungkapan Islamic Social Reporting (ISR).

Ukuran dewan pengawas syariah termasuk salah satu yang dapat mempengaruhi pengungkapan ISR karena dewan pengawas syariah bertugas mengawasi kegiatan perusahaan agar selalu menjalankan kegiatannya dalam prinsip syariah. Sehingga seperti yang dijelaskan dalam penelitian (Khoirudin, 2013) yang mana semakin banyak Dewan Pengawas Syariah maka pengawasan dalam pengungkapan islamic social reporting (ISR) semakin efektif dan level pengungkapan atas hal tersebut dapat meningkat, hal tersebut sesuai dengan penelitian yang dilakukan oleh (Ramadhani, 2016) bahwa ukuran dewan pengawas syariah berpengaruh terhadap pengungkapan ISR, sedangkan hasil alin yang telah diteliti oleh (Khoirudin, 2013) menyatakan bahwa ukuran dewan pengawas syariah tidak berpengaruh terhadap pengungkapan ISR. Beberapa ketidakonsistenan hasil riset penelitian terdahulu diatas menjadi alasan mengapa peneliti melakukan penelitian.

\section{TEORI DAN METODE}

\subsection{Islamic Social Reporting (ISR)}

Islamic Social Reporting (ISR) merupakan suatu konsep pertanggungjawaban sosial berbasis syariah yang muncul dari pemikiran peneliti yang berasal dari Malaysia bernama Ros Haniffa pada tahun 2002 yang kemudian dikembangkan lebih lanjut oleh peneliti-peneliti lain. Keberadaan konsep ini dilatarbelakangi oleh adanya 
anggapan bahwa dalam pelaporan pertanggungjawaban sosial konvensional terdapat keterbatasan yang mana tidak dapat diterapkan dalam lingkup syariah (Kurniawati \& Yaya, 2017).

Islamic Social Reporting (ISR) merupakan perluasan dari standar pelaporan kinerja sosial yang meliputi harapan masyarakat yang tidak hanya mengenai peran perusahaan dalam perekonomian, tetapi juga dalam perspektif spiritual, dan menekankan pada keadilan sosial terkait mengenai lingkungan, hak minoritas, dan karyawan. Islamic Social Reporting (ISR) memiliki dua tujuan utama, yaitu sebagai bentuk akuntabilitas kepada Allah SWT dan masyarakat serta untuk meningkatkan transparansi kegiatan bisnis dengan memberikan informasi yang relevan dan sesuai dengan kebutuhan para pembuat keputusan muslim.

\subsection{Agency Theory}

Agency Theory menggambarkan tentang hubungan antara pemilik perusahaan (principle) dan manajemen (agen). Dalam teori ini terdapat konflik keagenan antara kedua belah pihak yakni perbedaan tujuan antara principle dan agen, principle menghendaki untuk berupaya memaksimalkan laba sedangkan agen juga menghendaki mendapatkan kompensasi sesuai dengan kontrak, sehingga agen melakukan tindakan yang tidak sesuai dengan apa yang dikehendaki oleh principle (Rokhlinasari, 2015).

Kondisi tersebut muncul dikarenakan adanya asimetri informasi, yakni ketimpangan informasi yang dimiliki antara principle dan agen. Agen memiliki lebih banyak informasi internal yang berkaitan dengan perusahaan dibanding dengan principle. Teori agensi hadir untuk mengatasi konflik keagenan, untuk memenuhi stakeholder, agen mengungkapkan pertanggungjawaban sosial perusahaan. Para stakeholder akan puas melihat perusahaannya mengungkapkan pertanggungjawaban sosial sehingga dapat menambah kepercayaan masyarakat dan dapat memaksimalkan laba (Putri, 2017).

\subsection{Legitimacy Theory}

Legitimacy Theory merupakan suatu teori yang menghubungkan antara perusahaan dengan masyarakat. O'Donova dalam (Omran, 2015) menyatakan bahwa teori legitimasi merupakan teori yang menganggap bahwa suatu perusahaan dapat terus beroperasi serta dapat mencapai kesuksesan jika bertindak sesuai dengan batas batas serta norma yang ada dalam masyarakat. Teori legitimasi bergantung pada asumsi bahwa antara perusahaan dan masyarakat terdapat suatu kontrak sosial, yang dimaksud kontrak sosial tersebut adalah suatu cara untuk menjelaskan harapan masyarakat terhadap bagaimana seharusnya perusahaan beroperasi. Harapan sosial tersebut bersifat tidak tetap, namun menyesuaikan dengan perkembangan waktu sehingga suatu perusahaan harus lebih responsif terhadap lingkungan tempat mereka beroperasi (Rokhlinasari, 2015).

Teori ini juga menyebutkan bahwa jika perusahaan tidak menjalankan kegiatannya sesuai dengan batasan serta norma yang ada dalam masyarakat. Hal tersebut menyebabkan masyarakat tidak puas dengan kinerja perusahaan, sehingga masyarakat bisa saja memberikan tekanan terhadap perusahaan untuk memenuhi harapannya, atau hal lain masyarakat juga dapat menggunakan sistem hukum untuk mensyaratkan perusahaan (Mousa \& Hassan, 2015). Hal tersebut mensiratkan bahwa suatu perusahaan harus selalu menjaga hubungan baik dengan lingkungan serta 
masyarakat, karena keberlangsungan hidup perusahaan bergantung pada hubungan tersebut. Agar dapat terus beroperasi, suatu perusahaan harus selalu menunjukkan bahwa kegiatan yang dijalankannya sesuai dengan batasan-batasan yang ada, hal tersebut dapat dicapai dengan suatu pengungkapan dalam laporan perusahaan sehingga masyarakat bisa mengetahui apakah suatu perusahaan berjalan sesuai batasan atau sebaliknya.

\subsection{Stakeholder Theory}

Stakeholder Theory mengasumsikan bahwa eksistensi perusahaan ditentukan oleh stakeholder, sehingga aktivitas perusahaan juga mempertimbangkan persetujuan stakeholder, semakin kuat stakeholder maka perusahaan juga harus semakin beradaptasi dengan stakeholder. Berdasarkan karakteristiknya stakeholder dapat dibagi menjadi 2 jenis, yaitu stakeholder primer dan stakeholder sekunder. Stakeholder primer dapat diartikan sebagai seorang atau kelompok yang tanpanya perusahaan tidak dapat bertahan untuk going concern, stakeholder primer ini seperti investor, karyawan, pemasok dll. Sedangkan stakeholder sekunder merupakan mereka yang terdapat keterkaitan dengan perusahaan tetapi tidak berhubungan langsung terhadap transaksi serta kelangsungannya tidak esensial (Rokhlinasari, 2015).

Teori stakeholder menekankan bahwa perusahaan bukanlah entitas yang hanya beroperasi untuk kepentingannya sendiri melainkan juga memperhatikan kepentingan stakeholder dan sebisa mungkin dapat memberikan manfaat bagi stakeholdernya (Putri, 2017) . Teori ini juga menjelaskan bahwa dengan adanya pengungkapan pertanggungjawaban sosial dapat dijadikan sarana untuk berdialog dengan para stakeholder. Dengan diungkapkannya pertanggungjawaban sosial perusahaan diharapkan keinginan stakeholder dapat terpenuhi sehingga menciptakan hubungan yang harmonis antar perusahaan dengan stakeholdernya, yang mana hal tersebut dapat menjadi jalan untuk keberlanjutan perusahaannya.

\subsection{Syariah Enterprise Theory (SET)}

Syariah Enterprise Theory (SET) merupakan suatu teori yang digagas oleh Triyuwono, teori ini dikembangkan berdasarkan metafora zakat yang mana memiliki karakter keseimbangan, hal tersebut menjadikan Syariah Enterprise Theory (SET) tidak lagi hanya memperhatikan kepentingan individu (pemegang saham) tetapi juga mementingkan kepentingan pihak lain yakni stakeholder. Dalam konsep Syariah Enterprise Theory (SET) stakeholder meliputi 3 pihak, yaitu Tuhan, manusia dan alam (Triyuwono, 2011). Tuhan merupakan stakeholder tertinggi karena segala sesuatu hakikatnya kembali kepada Tuhan yang telah menciptakan dan merupakan satu satunya tujuan hidup manusia. Dengan menempatkan Tuhan menjadi stakeholder tertinggi maka seluruh kegiatan dijalankan berdasarkan atas aturan serta hukum Tuhan.

Stakeholder kedua yakni manusia, dalam hal ini dibedakan menjadi dua kelompok, yakni direct-stakeholder serta indirect-stakeholder. Direct-stakeholder yanki pihak pihak yang turut berkontribusi dalam perusahaan baik dalam hal financial maupun non financial, sedangkan indirect-stakeholder merupakan pihak pihak yang tidak memberi kontribusi kepada perusahaan baik dalam hal financial maupun non financial, tetapi menurut pandangan syariah tetap memiliki hak untuk mendapatkan kesejahteraan dari perusahaan. 
Stakeholder ketiga yakni alam, alam berperan sangat penting bagi kehidupan manusia karena alam memberikan sumberdaya yang dibutuhkan oleh manusia sehingga manusia bisa terus bertahan hidup, namun wujud kesejahteraan yang diberikan perusahaan bagi alam bukan dengan materi atau uang tetapi dengan turut serta menjaga alam serta melindunginya dari perlakuan buruk yang dapat merusaknya. Berdasarkan hal tersebut dapat kita lihat jika teori ini tidak menempatkan manusia sebagai pemangku kepentingan utama, namun menjadikan Tuhan sebagai kekuasaan tertinggi diatas segalanya, karena sejatinya Tuhan lah tempat kembali.

Menurut meutia dalam (Anwar \& Rajab, 2018) menyatakan bahwa teori yang paling tepat dalam mengungkapkan tanggung jawab sosial perusahaan terkhusus dengan berbasis syariah seperti perbankan syariah adalah Syariah Enterprise Theory (SET) karena didalam Syariah Enterprise Theory (SET) menempatkan Allah sebagai sumber amanah utama, sedangkan sumberdaya yang dimiliki oleh stakeholder lain sejatinya merupakan amanah dari Allah yang mana didalamnya melekat sebuah tanggung jawab untuk menggunakan dan mengelolanya dengan baik berdasarkan ketentuan-ketentuan yang telah ditetapkan oleh Allah SWT.

\subsection{Debt to Equity Ratio (DER)}

Menurut (Hantono, 2018) Debt to Equity Ratio (DER) adalah rasio untuk menunjukkan sejauh mana modal sendiri menjamin seluruh utang. Debt to Equity Ratio (DER) merupakan salah satu rasio yang ada dalam rasio Leverage, yang mana rasio leverage merupakan suatu rasio yang bertujuan untuk mengukur seberapa besar perusahaan dibiayai dengan utang. Semakin rendah nilai Debt to Equity Ratio (DER) maka dapat dikatakan semakin baik yang mana perusahaan mampu untuk menjamin seluruh utangnya.

Dalam menjalankan usahanya, perusahaan harus mampu menyeimbangkan antara berapa besar utang yang dapat diambil dengan mempertimbangkan darimana sumber-sumber yang dapat digunakan untuk melunasinya, karena dengan perusahaan mempunyai utang yang terlalu tinggi menyebabkan perusahaan masuk dalam extreme leverage yaitu perusahaan terjebak dalam utang yang tinggi dan sulit untuk melepaskan beban utang tersebut (Fahmi, 2017).

\subsection{Ukuran Dewan Komisaris}

Dalam Peraturan Bank Indonesia Nomor 11/33/PBI/2009 tentang Pelaksanaan Good Corporate Governance bagi Bank Umum Syariah dan Unit Usaha Syariah menyatakan bahwa Dewan Komisaris adalah organ perseroan yang bertugas melakukan pengawasan secara umum dan/atau khusus sesuai dengan anggaran dasar serta memberi nasihat kepada Direksi sebagaimana dimaksud dalam UndangUndang Nomor 40 Tahun 2007 tentang Perseroan Terbatas. Menurut (Khoirudin, 2013) Ukuran dewan komisaris adalah jumlah anggota dewan komisaris dalam suatu perusahaan. Dalam pasal 108 UU No 40 tahun 2007 juga dijelaskan bahwa suatu perseroan yang kegiatannya menghimpun/ mengelola dana, menerbitkan surat pengakuan utang atau perseroan terbuka diwajibkan minimal mempunyai 2 dewan komisaris di dalamnya.

Dewan komisaris mempunyai tugas dan tanggung jawab yang harus dijalankan sesuai dengan pasal 8 Peraturan Bank Indonesia Nomor 11/33/PBI/2009, tugas dan tanggung jawab tersebut adalah: 
1. Dewan Komisaris wajib melakukan pengawasan atas terselenggaranya pelaksanaan GCG dalam setiap kegiatan usaha BUS pada seluruh tingkatan atau jenjang organisasi

2. Dewan Komisaris wajib melaksanakan pengawasan terhadap pelaksanaan tugas dan tanggung jawab Direksi, serta memberikan nasihat kepada Direksi.

3. Dewan Komisaris wajib memantau dan mengevaluasi pelaksanaan kebijakan strategis BUS.

4. Dewan Komisaris dilarang terlibat dalam pengambilan keputusan kegiatan operasional BUS, kecuali pengambilan keputusan untuk pemberian pembiayaan kepada Direksi sepanjang kewenangan Dewan Komisaris tersebut ditetapkan dalam Anggaran Dasar BUS atau dalam Rapat Umum Pemegang Saham.

\subsection{Ukuran Dewan Pengawas Syariah}

Dewan Pengawas Syariah adalah dewan yang bertugas memberikan nasihat dan saran kepada Direksi serta mengawasi kegiatan Bank agar sesuai dengan Prinsip Syariah sebagaimana yang dijelaskan dalam Peraturan Bank Indonesia Nomor 11/33/PBI/2009 tentang Pelaksanaan Good Corporate Governance bagi Bank Umum Syariah dan Unit Usaha Syariah. Sedangkan berdasarkan Surat Keputusan Dewan Syari'ah Nasional no.3 tahun 2000 Dewan Pengawas Syariah (DPS) adalah bagian dari Lembaga Keuangan Syariah yang bersangkutan, yang penempatannya atas persetujuan Dewan Syariah Nasional (DSN). Dewan Pengawas Syariah (DPS) adalah suatu badan yang bertugas mengawasi pelaksanaan keputusan DSN di lembaga keuangan syariah. DPS diangkat dan diberhentikan di lembaga keuangan syariah melalui RUPS setelah mendapat rekomendasi dari DSN. Ukuran Dewan Pengawas Syariah menurut (Khoirudin, 2013) adalah jumlah dari anggota dewan pengawas syariah dalam suatu perusahaan.

Dewan Pengawas syariah mempunyai tugas yang harus dijalankan, tugas tersebut adalah mendiskusikan mengenai masalah masalah serta transaksi usaha yang terjadi kemudian membuat keputusan mengenai sesuai ataupun tidaknya suatu transaksi dengan prinsip syariah (Misbach, 2015). Dalam pasal 109 UU no 40 tahun 2007 juga dijelaskan bahwa Dewan Pengawas Syariah bertugas memberikan nasihat dan saran kepada Direksi serta mengawasi kegiatan Perseroan agar sesuai dengan prinsip syariah. Adapun fungsi dari dari Dewan Pengawas Syariah adalah:

1. DPS melakukan pengawasan secara periodik pada lembaga keuangan syariah yang berada di bawah pengawasannya

2. DPS berkewajiban mengajukan usul-usul pengembangan lembaga keuangan syariah kepada pimpinan lembaga yang bersangkutan dan kepada DSN.

3. DPS melaporkan perkembangan produk dan operasional lembaga keuangan syariah yang diawasinya kepada DSN sekurang-kurangnya dua kali dalam satu tahun anggaran.

4. DPS merumuskan permasalahan-permasalahan yang memerlukan pembahasan DSN.

\subsection{Metode Penelitian}

Penelitian ini dilakukan dengan menggunakan metode kuantitatif. Penelitian ini dilakukan pada Bank Umum Syariah yang berada di Indonesia dalam kurun waktu tahun 2017-2019 melalui website masing-masing bank. Sampel dalam 
penelitian ini adalah Bank Umum Syariah yang terdaftar di Otoritas Jasa Keuangan pada tahun 2017-2019. Teknik pengambilan sampel dalam penelitian ini adalah menggunakan teknik purposive sampling yakni cara menentukan sampel sesuai dengan pertimbangan/kriteria yang telah ditetapkan sebelumnya. Dalam penelitian ini kriteria pengambilan sampel yang digunakan adalah sebagai berikut:

1. Bank Umum Syariah yang terdaftar di Otoritas Jasa Keuangan tahun 20172019

2. Bank Umum Syariah yang mempublikasi laporan keuangan tahunan serta laporan CSR berturut-turut dari tahun 2017-2019.

3. Bank Umum Syariah yang memuat data berkaitan dengan variabel penelitian.

Tabel 2. Pengambilan Sampel

\begin{tabular}{l|c}
\hline \multicolumn{1}{c|}{ Kriteria } & Jumlah \\
\hline BUS yang terdaftar di OJK hingga tahun 2019 & 14 \\
\hline $\begin{array}{l}\text { BUS yang tidak mempublikasi laporan keuangan } \\
\text { atau laporan CSR }\end{array}$ & $(2)$ \\
\hline Jumlah Sampel & 12
\end{tabular}

Sumber :data diolah sendiri, 2020

Tabel 3. Daftar Sampel Perusahaan

\begin{tabular}{c|l|c}
\hline No & \multicolumn{1}{|c|}{ Nama Bank Umum Syariah } & Kode \\
\hline 1. & PT. BCA Syariah & BCAS \\
\hline 2. & PT. Bank Rakyat Indonesia Syariah & BRIS \\
\hline 3. & PT. Bank Syariah Mandiri & BSM \\
\hline 4. & PT. Bank Mega Syariah & BMS \\
\hline 5. & PT. Bank Syariah Bukopin & BSB \\
\hline 6. & PT. Maybank Syariah Indonesia & BMSI \\
\hline 7. & PT. BPD Nusa Tenggara Barat Syariah & BNIS \\
\hline 8. & PT. BNI Syariah & \\
\hline 9. & PT. Bank Panin Dubai Syariah & BJBS \\
\hline 10. & PT. Bank Jabar Banten Syariah & \\
\hline 11. & PT. Bank Aceh Syariah & BMIS
\end{tabular}

\section{HASIL DAN PEMBAHASAN}

\subsection{Hasil Analisis Data}

Berdasarkan hasil uji staristik peneliti, maka maka hipotesis pertama yang diajukan (H1) yakni Leverage (X1) memberi pengaruh pada pengungkapan Islamic Social Reporting (ISR), ditolak karena nilai t hitung 0,963 serta t tabel 1,983 bermakna nilai t hitung $<\mathrm{t}$ tabel $(0,963<1,983)$ dengan $\mathrm{p}$ value (sig) 0,343 $(>0,05)$. Sehingga, variabel leverage tidak memberi pengaruh pada pengungkapan Islamic Social Reporting (ISR). Hipotesis kedua (H2) yakni ukuran dewan komisaris (X2) memberi pengaruh pada pengungkapan Islamic Social Reporting (ISR), diterima karena nilai t hitung 2,167 serta t tabel 1,983, bermakan nilai $t>t$ tabel $(2,167>1,983)$ dengan $p$ value $(\operatorname{sig}) 0,007(<0,05)$. Sehingga, variabel ukuran dewan komisaris memberikan pengaruh terhadap pengungkapan Islamic Social Reporting (ISR). Hipotesis ketiga (H3) yakni Ukran dewan pengawas 
syariah (X3) memberi pengaruh pada pengungkapan Islamic social reporting (ISR), ditolak karena nilai $\mathrm{t}$ hitung 0,736 serta $\mathrm{t}$ tabel 1,983 bermakna nilai $\mathrm{t}$ hitung $<t$ tabel $(0,736<1,983)$ dengan $p$ value $(\operatorname{sig}) 0,088(>0,05)$. Sehingga, variabel ukuran dewan pengawas syariah tidak memberikan pengaruh pada pengungkapan Islamic Social Reporting (ISR).

\subsection{Pembahasan}

\section{a) Pengaruh Leverage terhadap Islamic Social Reporting (ISR)}

Hipotesis pertama (H1) yang dirumuskan dalam penelitian ini bahwa leverage berpengaruh terhadap pengungkapan Islamic Social Reporting (ISR). Namun, hasil pengujian statistik secara parsial menunjukkan bahwa leverage tidak berpengaruh terhadap pengungkapan Islamic Social Reporting (ISR). Dengan kata lain, besar kecilnya hutang tidak lantas memberikan dampak pengaruh terhadap besar kecilnya pengungkapan kinerja sosial perbankan syariah. Hasil penelitian ini sejalan dengan penelitian Lestari (2015) dan Eksandy dan Hakim (2015) yang menunjukkan bahwa leverage tidak berpengaruh terhadap pengungkapan Islamic Social Reporting (ISR). Hasil penelitian ini tidak sejalan dengan penelitian sebelumnya yang dilakukan oleh Astuti (2014), Anggraini dan Wulan (2015), dan Ramadhani (2016) yang menyatakan bahwa leverage berpengaruh terhadap pengungkapan Islamic Social Reporting (ISR). Leverage yang diukur dengan rasio kewajiban terhadap ekuitas pada bank syariah akan berbeda dengan entitas lainnya. Kewajiban pada bank syariah merupakan sumber utama penghasilan laba dengan sistem bagi hasil nisbah keuntungan. Sedangkan pada entitas non syariah, kewajiban merupakan suntikan modal untuk memaksimalkan laba. Hal ini menandakan bahwa pengungkapan tanggung jawab sosial secara syariah pada perbankan syariah telah menjadi suatu kewajiban baik dalam kondisi leverage rendah maupun tinggi.

\section{b) Pengaruh Ukuran Dewan Komisaris terhadap Islamic Social Reporting} (ISR)

Variabel Ukuran Dewan Komisaris berpengaruh signifikan terhadap Islamic Social Reporting ini dapat disebabkan oleh rata-rata UDK pada BUS selama periode 2017-2019 sebesar 63,46\%. Berdasarkan peraturan Bank Indonesia Nomor 11/33/PBI/2009 tentang pelaksanaan Good Corporate Governance bagi Bank Umum Syariah dan Unit Usaha Syariah menyatakan bahwa anggota dewan komisaris independen minimal 50\% dari anggota dewan komisaris. Hal ini menunjukkan jumlah dan komposisi dari komisaris independen telah sesuai dengan ketentuan yang berlaku, sehingga dapat disimpulkan bahwa keberadaan komisaris independen pada BUS dapat meningkatkan perlindungan bagi kepentingan pemangku khususnya nasabah pemilik dana dan pemegang saham minoritas dan menghindari benturan kepentingan dalam pelaksanaan tugas serta memberikan kontribusi yang efektif terhadap hasil dari proses penyusunan laporan keuangan yang berkualitas atau kemungkinan terhindar dari kecurangan laporan keuangan. Hasil penelitian ini mendukung penelitian yang dilakukan oleh Gestari (2014) yang menyatakan bahwa ukuran dewan komisaris independen berpengaruh signifikan terhadap ISR. 


\section{c) Pengaruh Ukuran Dewan Pengawas Syariah terhadap Islamic Social Reporting}

Variabel Ukuran Dewan Pengawas Syariah tidak memberikan pengaruh terhadap pengungkapan Islamic Social Reporting (ISR). Penyebabnya mungkin jumlah dewan pengawas syariah yang besar tidak akan membuat pengawasan terhadap pemenuhan prinsip syariah dalam kegiatan usaha Bank Umum Syariah lebih efektif. Tugas pokok dan concern utama dari dewan pengawas syariah adalah dalam hal kepatuhan syariah antara lain mengawasi kegiatan menyalurkan dana zakat, infak, sedekah yang bisa diakui sebagai bentuk Islamic Social Reporting perusahaan. Jadi tidak dapat dipungkiri bahwa dewan pengawas syariah dalam jumlah yang cukup banyak dengan beragam perspektif, pengalaman, kompetensi baik dalam bidang perbankan dan keuangan, serta keahlian dalam hal hukum Islam tidak menjamin membuat kinerja bank semakin efektif dan dapat mengakibatkan review pada pelaporan perusahaan jadi lebih baik terutama dalam hal tata kelola perusahaan dan pengungkapan Islamic Social Reporting. Hasil penelitian ini tidak sesuai dengan penelitian Ningrum dkk. (2013) yang menemukan bahwa ukuran dewan pengawas syariah berpengaruh terhadap pengungkapan Islamic Social Reporting.

\section{PENUTUP}

Hasil penelitian menunjukkan bahwa leverage tidak berpengaruh terhadap pengungkapan Islamic Social Reporting (ISR). Namun, Ukuran Dewan Komisaris berpengaruh positif signifikan terhadap pengungkapan Islamic Social Reporting (ISR) dan Ukuran Dewan Pengawas Syariah tidak berpengaruh terhadap pengungkapan Islamic Social Reporting (ISR). Saran penelitian selanjutnya ialah menambah periode waktu penelitian sehingga mendapatkan hasil yang lebih baik, khususnya untuk variabel leverage dan dewan pengawas syariah yang masing-masing tidak berpengaruh terhadap pengungkapan Islamic Social Reporting dengan mengganti proksi, misalnya ukuran dewan pengawas syariah menggunakan perbandingan persentase dewan pengawas syariah dibandingkan jumlah dewan pengawas. Selain itu menambah sampel pengamatan menggunakan seluruh jenis Bank Syariah di Indonesia seperti Unit Usaha Syariah (UUS) dan Bank Perkreditan Rakyat Syariah (BPRS) di Indonesia dan menambahkan variabel atau faktor lain terhadap pengungkapan Islamic Social Reporting. 


\section{DAFTAR PUSTAKA}

Anwar, S. M., \& Rajab, N. A. (2018). Analisis Pengungkapan Tanggungjawab Sosial Perbankan Syariah dalam Perspektif Syariah Enterprise Theory. Jurnal Manajemen, 4(1), 8-12.

Baidok, W., \& Septiarini, D. F. (2016). Pengaruh Dewan Komisaris, Komposisi Dewan Komisaris Independen, Dewan Pengawas Syariah, Frekuensi Rapat Dewan Komisaris Syariah dan Frekuensi Rapat Komite Audit terhadap Pengungkapan Indeks Islamic Social Reporting pada Bank Umum Syariah Periode 2010-2014. Jurnal Ekonomi Syariah Teori dan Terapan .

Eksandy, A., \& Hakim, M. Z. (2017). Pengaruh Ukuran Perusahaan, Profitabilitas dan Leverage terhadap Pengungkapan Islamic Social Reporting (ISR). Seminar Nasional and the 4th Call of Syariah Paper.

Fahmi, I. (2017). Analisis Laporan Keuangan. Bandung: Alfabeta.

Fitria, S., \& Hartanti, D. (2010). Islam dan Tanggungjawab sosial : Studi Perbandingan Pengungkapan Berdasarkan Global Reporting Initiative Indeks dan Islamic Social Reporting Indeks. SNA XIII .

Haniffa, R. (2002). Social Reporting Disclosure : an Islamic Perspective. Indonesian Manajement and Accounting Research .

Hantono. (2018). Konsep Analisa Laporan Keuangan dengan Pendekatan Rasio dan SPSS. Yogyakarta: CV. Budi Utama.

Hardani dkk. (2020). Metode Penelitian Kualitatif \& Kuantitatif. Yogyakarta: CV. Pustaka Ilmu Group Yogyakarta.

Hasan, M. I. (2016). Pokok-Pokok Materi Statistik 1 (Statistik Deskriptif). Jakarta: PT. Bumi Aksara.

Hasanah, N. T., Widiyanti, N. W., \& Sudarno. (2017). Analisis Pengaruh GCG dan Kinerja Keuangan Terhadap Pengungkapan Islamic Social Reporting (ISR). Ekonomi Bisnis dan Akuntansi, 5(2), 115-120.

Hasanah, S. M., \& R. K. (2019). Konsep Islamic Corporate Governance Fakultas Ekonomi dan Bisnis Islam UIN Mataram. Iqtishaduna, 10(1), 1-24.

Istifaroh, A., \& Subardjo, A. (2017). Faktor-Faktor yang Mempengaruhi Pengungkapan Corporate Social Responsibility. Jurnal Ilmu dan Riset Akuntansi, 6(6), 1-19.

Khoirudin, A. (2013). Corporate Governance dan Pengungkapan Islamic Social Reporting pada Perbankan Syariah di Indonesia. Accounting Analysis Journal , 228, 2(2), 227-232.

Kurniawati, M., \& Yaya, R. (2017). Pengaruh Mekanisme Corporate Governance, Kinerja Keuangan dan Kinerja Lingkungan terhadap Pengungkapan Islamic Social Reporting. Jurnal Akuntansi dan Investasi, 18(2), 163-171.

Misbach, I. (2015). Kedudukan dan Fungsi dewan Pengawas Syariah dalam Mengawasi Transaksi Lembaga Keuangan Syariah di Indonesia. Manajemen Ide dan Inspirasi .

Mousa, G. A., \& Hassan, N. T. (2015). Legitimacy Theory and Environmental Practices : Short Notes. International Journal of Business and Statistical Analysis, 2(1), 41-53.

OJK. (2020). Pasar Modal Syariah November 2020.

Omran, M. A. (2015). Theoretical Perspectives on Corporate Social Responsibility Disclosure : A Critical Review. International Journal of Accounting and Financing Reporting, 5(2), 38-55.

Othman, R., \& Thani, A. M. (2010). Islamic Social Reporting of Listed Companies in 
Malaysia. International Business \& Economics Research, 9(4), 135-144.

Putri, R. K. (2017). Pengaruh Ukuran perusahaan, Profitabilitas, Leverage, Likuiditas dan Basic Kepemilikan terhadap Corporate Social Responsibility pada Perusahaan Pertambangan yang terdaftar di Bursa Efek Indonesia periode tahun 2012-2014. JOM Fekon, 4(1), 558-571.

Rama, A., \& Meliawati. (2014). Analisis Determinan Pengungkapan Islamic Social Reporting: Studi Kasus Bank Umum Syariah di Indonesia. Equilibrium Jurnal Ekonomi Syariah, 2(1), 952-1115.

Ramadhani, F. (2016). Pengaruh Ukuran Perusahaan, Profitabilitas, Leverage dan Ukuran Dewan pengawas Syariah terhadap Pengungkapan Islamic Social Reporting. JOM Fekon, 3(1), 2487-2500.

Rosiana, R., Arifin, B., \& Hamdani, M. (2015). Pengaruh Ukuran Perusahaan, Profitabilitas, Leverage dan Islamic Governance Score terhadap Pengungkapan Islamic Social Reporting. Jurnal Bisnis dan Manajemen, 5(1), 87-104.

Rostiani, S. S., \& Sukanta, T. A. (2018). Pengaruh Dewan Pengawas Syariah, Profitabilitas dan Leverage terhadap Pengungkapan Islamic Social Reporting (ISR). Jurnal Akuntansi Bisnis dan Ekonomi, 4(2), 1225-1248.

Sawitri, D. R., Juanda, A., \& Jati, A. w. (2017). Analisis Pengungkapan Corporate Social Responsibility Perbankan Syariah Indonesia Berdasarkan Islamic Social Reporting Index. Jurnal Ilmiah akuntansi : Kompartemen, 15(2), 139-149.

Siyoto, S., \& Sodik, M. A. (2015). Dasar Metodologi Penelitian. Yogyakarta: Literasi Media Publishing.

Sofyani, H., Ulum, I., Syam, D., \& L, S. W. (2012). Islamic Social Reporting Index Sebagai Model Pengukuran Kinerja Sosial Perbankan Syariah (Studi Komparasi Indonesia dan Malaysia). Jurnal Dinamika Akuntansi, 4(1), 36-46.

Sugiyono. (2016). Metode Penelitian Kuantitatif, Kualitatif dan R\&D. Bandung: ALFABETA. 